\title{
Regulation of hexokinase and glucose-6-phosphate dehydrogenase genes expression at norm and pathology
}

\author{
R. Yu. Marunych \\ ESC «Institute of Biology», Taras Shevchenko National University of Kyiv \\ 64/13, Volodymyrska Str., Kyiv, Ukraine, 01601 \\ nautilus999@gmail.com
}

\begin{abstract}
The increasing of glycolysis in tumors under aerobic conditions is known as Warburg phenomenon; the activity of the pentose phosphate pathway increases also significantly. The pentose phosphate pathway and glycolysis, especially their first steps, and the regulatory enzyme 6-phosphofrukto-2-kinase/fructose-2,6-bisphosphatase are influenced by cell signaling systems such as the system of circadian clock, the system of hypoxia-inducible factor and unfolded protein response system, that allow malignant cells to adapt to stress factors such as hypoxia, ischemia and influence of low molecular agents. The review enlightens the impact of signaling systems on the key enzymes of glycolysis and the pentose phosphate pathway gene expression in normal cells and in malignant cells, and their importance for survival of malignant cells under stress conditions.
\end{abstract}

Keywords: hexokinase, glucose-6-phosphate dehydrogenase, gene expression, stress.

Composition and expression of hexokinase and glucoso-6-phosphate dehydrogenase genes. Both glycolysis and pentose phosphate pathway are important at norm and pathology. These processes are vital; the changes, occurring during oncotransformation of cells, evoke considerable activation of the abovementioned metabolic pathways to satisfy the needs of cells regarding reducing equivalents, energy and ribose for nucleic acid synthesis. Among different pathologies, related to glucose metabolism, the most common are diabetes and oncological diseases, among the most life-threatening oncological diseases are brain tumors, in particular, glioma and glioblastoma. Increased glycolysis in oncotransformed cells in aerobic conditions is known as Warburg effect. Hexokinases and glucoso-6-phosphate dehydrogenase are essential for the utilization of external glucose by the cell.

The enzymes of hexokinase family in vertebrates are encoded by independent genes, located on different chromosomes [1]. Contrary to rats, humans have got a pseudogene of the second hexokinase-2, located on

(C) Institute of Molecular Biology and Genetics, NAS of Ukraine, 2013
$\mathrm{X}$-chromosome in locus q21.1. The gene of the first isoenzyme, known as brain hexokinase, is located on human chromosome 10 , locus q22, and on rat chromosome 20, locus q11. Human hexokinase-1 gene, about 131 thousand b.p., contains 25 exons, including seven alternative ones: one erythroid-specific exon and six testis-specific exons [2]. The products of this gene are remarkable for alternative splicing which results in the formation of five splice-isoforms with different unique regulatory $\mathrm{N}$-terminal sites [3]. The expression of splice-isoforms is partially tissue-specific. Alternative non-translated exons, for instance, AltT2, are essential for protein functioning in the nervous system; mutation in these exons may result in neuropathy development. The specificity of the gene is the absence of TATA-box and the presence of inverted sequence of GATA and erythroid promoter at 5 '-end. Sequence from -275 to -229 contains consensus motifs for transcriptional factors SP-1 and GATA, CCAAT- and GGAA-motifs, required for the expression in erythroid cells. The alternative transcription with further alternative splicing, when an additional exon is involved in the sequence, causes the formation of mRNA in erythroid 
cells, encoding HK-R-specific erythroid splice-isoform of hexokinase-1, present in erythroid cells along with HK1 [4]. The mutations in the promoter area by AR-1 factor site result in the deficiency of this enzyme in erythroid cells. The expression of the mentioned gene depends on HIF-1 $\alpha$ [5]. Motif CTGTC, remarkable for the promoter of pyruvate kinase, was also revealed. The element PKR-RE1 may also activate HK1 gene [6]. In the experiment the expression of this gene in normal and diabetic rats was induced by vegetative growth regulator, 28-homobrassinosteroid [7].

The gene of muscle isoform of hexokinase- 2 is located on human chromosome 2 , locus $\mathrm{p} 13$, and on rat chromosome 4 , locus q34. The gene contains 18 exons, and it was demonstrated that the mutations in exons 4 and 17 are capable of causing the development of insulin-independent diabetes [8]. This isoform of NA1 was called a muscle isoform, but it is expressed in many tissues, including adipose tissue and the heart muscle [8], the increase in its expression is remarkable for tumor cells, including fast growing tumors [9]. The inhibition of HK1 expression makes cells sensitive to proapoptotic factors [10]. The promoter contains two elements for binding p53, and the expression of this gene is also activated at the effect of HIF and insulin [11]. As the promoter has a sterol-regulatory element (SRE) in position from -369 to -270 , recognized by protein SREBP-1c, the gene is activated by insulin [12] A remarkable specificity of liver tumors is the correlation between the expression of $H K 2$ and $V E G F$, on the one hand, and $H I F-1 \alpha-$ on the other [13]. Hypoxia enhances cell proliferation of liver tumors due to the HK2 expression activation [14]. However, the hyperexpression of genes of proteins, inhibiting angiogenesis (TROP and ASTAT) is also known to cause the activation of a number of glycolytic genes, including the ones, encoding HK2 and HK1 [15]. Another activator of glycolytic enzyme genes is interleukin 6 . Its effect is mediated by signal transducer and transcription activator 3 (STAT3), activating the expression of $H K 2$ and 6-phosphofructo-2-kinase/fructoso-2,6-bisphosphatase-3 $(P F K F B 3)$ in murine fibroblasts and human cell lines [16].

Hexokinase 3, or a lymphocytic form of hexokinase, is encoded by the gene, located on human chromosome 5 , locus q35.2, and rat chromosome 17 , locus q12
[17]. Although this isoform is called "lymphocytic", its expression is remarkable for liver and lungs as well, and the aminoacid sequence is $87 \%$ homologous for rats and humans [18]. This isoform was revealed in kidneys, brain and spleen; $H K 1$ and $H K 3$ expression in rats depends on age and varies during the development [19]. According to other data, the expression of the abovementioned enzyme and VEGF, HIF- 16 and HK2 correlates with the accumulation of fluorine-18-stained glucose by breast tumors [20]. It became possible to relate the patterns of hexokinase expression, including hexo kinase-3, and high-affinity transporters of glucose for esophageal adenocarcinoma [21]. The mutations of hexokinase-3 gene are specific for rectal and breast tumors [22].

Contrary to three abovementioned hexokinases with molecular weight up to $100 \mathrm{kDa}$, the fourth hexokinase, or glucokinase, is the smallest, its molecular weight is about $50 \mathrm{kDa}$. In humans, glucokinase is encoded by the gene, located on chromosome 7 , locus p15.3-p15.1, while in rats it is on chromosome 14, locus q21. The gene consists of 12 exons, varying in their size from 96 to 977 b.p., a TATA-box and the site of binding transcriptional factor Sp1. It is assumed that the genes of first three hexokinases were formed due to duplication and merging of glucokinase gene [23].

Three tissue-specific splice-isoforms of this enzyme were discovered - two in liver and one in pancreatic $\beta$-cells. Pancreatic splice-isoform differs by the first exon, which is unique and has a modified 5'-UTR, affecting $\mathrm{N}$-end of the protein. The formed protein has a modified N-end. Splice-isoform-2 is a dominating splice-isoform of liver; it has a modified $\mathrm{N}$-end and is remarkable for the presence of a specific first exon of liver isoform and the absence of the third exon, notable for minor splice-isoform 3 of liver.

The increase in glucose level does not affect the expression of glucokinase in $\beta$-cells of pancreas. The expression of glucokinase gene in these cells is rather not dependent on hormones and activity of metabolism enzymes [24]. It allows performing the function of sensing glucose. However, the situation is more complicated in hepatocytes - glucokinase in their composition is more sensitive to insulin (increasing the expression) and glucagon, working via cAMP, evoking glucokinase inactivation by protein kinase A [25]. 
The effect of insulin is caused by binding the transcriptional factor HNF-4 with the promoter element HBEs, but it is inhibited by FOXO1 factor [26]. The promoter site of glucokinase gene in hepatocytes also contains SRE-sequence and SP-site, interacting with the proteins SREBP-1 $\alpha$ and SP1, thus activating the expression of this gene in liver in response to insulin $[27,28]$. The regulatory area of the gene contains sites of binding factors ERR $\alpha$ and PGC-1 $\alpha$, activating its expression [29]. In general, the regulation of glucokinase gene expression in hepatocytes is multi-level, as both the transcription and mRNA of this gene are subject to regulation [30]. Fructoso-2,6-bisphosphate is a powerful activator of the liver glucokinase gene expression, as it is capable of maintaining it in the absence of insulin [30], which is conditioned by the unique tissuespecific structure of the promoter area of this gene [31].

There are many known mutations of the glucokinase gene, often related to different pathologies, like diabetes [32]. For instance, polymorphism of the promoter site -30 may be related to obesity [33]. Mutations are divided into activating (T65I, W99R, V455M, A456V) and inactivating (N161) or neutral (R397L) [34]. Their majority occur in the center of allosteric regulation for low-molecular compounds, located opposite the active center, rather than in the active center of the enzyme [35]. The specificity lies in the fact that the frequency of mutations, affecting kinetics, is higher for a small domain compared to the big one (though it is regulatory) [36]. It was demonstrated that activation mutations usually result in hypoglycemia, while inactivating ones - in hyperglycemia, as the function of "sensing" glucose in $\beta$-cells is impaired. There are also mutations, hindering the formation of complexes with the regulatory protein of glucokinase (GCKRP) and the enzyme inactivation with the transition into the nucleus (mutation R308W) [37]. Mutation V182M increases the formation of complexes with GCKRP.

Contrary to the considered families of $H K$ genes, glucoso-6-phosphate dehydrogenase is encoded by one gene, located on human X-chromosome, locus q28 [38]. Two splice-isoforms were characterized: a - large isoform, consisting of 545 amino acid residues [39] that is catalytically inactive, as it has an insert, but it may be subject to being processed and to transform into a smaller splice-isoform - b (515 a.r.) with a shorter
N-end, mRNA of which has a unique 5'-UTR [40]. The latter splice-isoform is catalytically active. The promoter has a TATA-box [41] and seven GC-boxes, minimum two of which are required for the promoter activation. The SP-1- and AP-2-like proteins bind to these two boxes [42]. There are many known pathologies, related to the states of this enzyme deficiency and its various mutations, including neonatal jaundice [43], impairment of $\beta$-cells in conditions of high glucose content at diabetes [44], chronic erythrolysis and megalocytic anemia [45], polycyctic ovarian disease [46], etc. Most mutations are replacements of one or several nucleotides in the regulatory sites or in the exons, and natural populations are saturated with many alleles [47].

The promoter site of the gene contains elements, securing increased expression in response to insulin, which also requires the activity of kinases PI3 and S6 [48]. There is observed response to palmitate and oleate, which may be conditioned by one or several factors, interacting with this gene promoter: liver nuclear factor $(\mathrm{NF})-4 \alpha$, protein $\mathrm{CAAT} / \beta$, binding the enhancer, PPAR $\alpha$, activator of chicken ovalbumin promoter (COUP-TF), binding protein of cAMP-regulatory element, and NF- $\mathrm{KB}$ [49]. The expression of this gene is increased in case of combined effect of insulin and triiodothyronine, but it has no adrenergic regulation [50]. Insignificant increase in the expression may be mediated by HIF effect and is revealed in response to hypoxia, but it is eliminated by antioxidants: glutathione and $\mathrm{N}$-acetylcysteine [51]. The expression regulation via processing of the G6PDH mRNA was determined in response to feeding or starvation of animals; here excessive feeding resulted in considerable increase in the level and accumulation of mRNA after splicing [52].

Therefore, the genes, encoding the enzyme of first stages of carbohydrate metabolism, are regulated in good coordination at the level of the organism with the mediation of hormones, insulin and glucagon predominantly, while at the cellular level the expression is defined by transcriptional factors, mainly including HIF (in case of glycolytic pathway genes). The genes of $H K$ and G6PDH families, located on different chromosomes, are remarkable for eukaryote-typical exon-intron composition and regulated by their own 
cys-regulatory elements. In majority of cases the gene expression evokes the formation of splice-isoforms, some of which are relatively tissue-specific.

The effect of cell signaling systems on the expression of genes of hexokinases and glucoso-6-phosphate dehydrogenase. Some genes of glucose metabolism have circadian oscillation of expression, controlled by the cell clock [53]. The cell clock, known as a biological clock, is perceived as a combination of genes and their products, forming the molecular intracellular oscillator, regulated by the loops of negative feedback at the level of transcription and translation. This mechanism secures the existence of the organism in cyclically changing environment.

Molecular components of the cell clock are divided into positive and negative elements [54]. Positive elements form heterodimers - transcriptional factors, and activate the transcription of negative element genes. CLOCK and BMAL1 are found in mammals [55]. These transcriptional factors contain structural domains PAS (PER-Arnt-Sim) and basal HLH (basic helix-loop-helix) [56]. Monomers form heterodimers (CLOCK:BMAL1) and activate the transcription of genes of the circadian clock. Negative elements in mammals are PER1-3 and CRY1 and 2 [57]. Negative elements inhibit the transcriptional activity of the positive ones, reducing the yield of their protein products. Positive elements have common homology in the structure of domains, while negative ones do not. The products of both positive and negative elements are characterized by oscillation in the course of 24 hours, and the level of products of negative elements fluctuates much more. The functioning of the cell clock is also regulated by protein kinases, kinases CK1e and MAP phosphorylate BMAL1 in vitro [58, 59].

It was revealed that the level of mRNA expression for circadian factors BMAL1, CLOCK and PER1 in brain, heart, testis and lungs of rats during 24 hours changes unevenly; these changes are tissue-specific and coordinated with different functional values of these tissues in metabolism of animals and possible effect on behavior [60].

It was determined that casein kinase-1e binds to PER1, PER2 and PER3 and phosphorylates them. It changes the functioning of genes [61, 62], controlling the cycle of cell division (Cyclin D1, Cyclin A,
MDM-2, c-MYC and GADD45alpha) and oncogenes as well as genes, inhibiting growth of tumors [63]. The abovementioned protein kinase phosphorylates BMAL1 and cryptochromes [64], participates in destabilization of catenin-degrading complex, in the functioning of signaling cascade TGF- $\beta$ [65], in the inactivation of protein bid via its being splitting by caspase 8 [66], phosphorylates P53 - protein, inhibiting tumor growth [67], regulates negatively phospho-Akt via the homologue of phosphatase and tensin PTEN [68].

In addition, there is reductive-oxidative control over the formation of heterodimer CLOCK:BMAL1 [69]. There are data, testifying to time-dependent regulation of subcellular localization of protein CLOCK in suprachiasmatic nucleus with the important role of BMal1 in this process $[70,71]$. The regulation involves nuclear orphan receptors of retinoic acid Rev-erb $\alpha$ and Rora (suppressing the expression of CLOCK and BMAL1 [72]). The transcriptional factors DEC1 and DEC2, containing domain bHLH, are regulated by the circadian clock, inhibiting the transcription, initiated by complex CLOCK:BMal1 [73].

The genes, regulated by CLOCK:BMAL1, should contain the regulatory sequence E-box, while regulated by Rev-erb $\alpha$ and Ror $\alpha$ need RORE. The genes PER1, PER 2 and PER 3 are known for mammals; all Per proteins contain domains PAS. The genes PER and $C R Y$ have stable circadian oscillations at the levels of mRNA and protein. Their peak is registered in the middle of light day part [74].

There is positive and negative correlation between mRNA for about 5,000 adipose tissue genes and mRNA PER1. Gene expression was reduced from the morning till the evening. Among genes, related to the circadian system, there are many genes of lipometabolism, synthesis of cholesterol, growth factors and metabolism of carbohydrates. They include PFKFB and its inducible isoform (PFKFB-3) [75]. The level of its mRNA is in positive correlation with the level of mRNA PER1.

PER and CRY are also capable of inhibiting the transcription of their own genes, affecting via heterodimer CLOCK:BMAL1. Since there is a reductiveoxidative control over the formation of heterodimer CLOCK:BMAL1 [76], there is a possibility of reverse mediated effect of carbohydrate metabolism, in particular, glycolytic and pentose phosphate pathways on 
the cellular clock via the reductive-oxidative state of the cytoplasm. The reductive-oxidative state of the cytoplasm is known to change at carcinogenesis. However, it is hardly the only agent, causing changes in the functioning of the cellular clock in tumors [77].

It was demonstrated that there is an inverse relation between the cellular clock of peripheral tissues and the level of glucose, as the increase in glucose content reduces the level of mRNA PER1 and PER2 indirectly. However, it was proven that this control was not related to the change in the reductive-oxidative state of the cytoplasm and the stabilization of dimer CLOCK: BMAL1 (capable of activating genes, containing E-box), rather it took place in a different way [78].

Another element of the cellular clock system nuclear receptor Rev-erb $\alpha$ - controls the expression of a number of genes of adipose tissue and liver. It was demonstrated that Rev-erb $\alpha$ represses the synthesis of apolipoprotein CIII and glucoso-6-phosphatase, thus inhibiting gluconeogenesis in liver. Indirect effect on gluconeogenesis and glycolysis of cryptochrome-1 blocks glucagon-mediated increase in cAMP level, decreasing the activation of cAMP-dependent proteinkinase A, phosphorylating a considerable amount of enzymes of carbohydrate exchange - hexokinases, PFKFB and G6PDH [79]. According to the current data, CLOCK directly activates the expression of glycogen synthetase-2 with remarkable circadian oscillations and two E-boxes in the promoter [80]. Direct regulation of steroid contra-insulin hormones, regulating many stages of carbohydrate exchange, by glucocorticoids, was also revealed for circadian gene PER2, the promoter of which contains GRE sites (sensitive to glucocorticoids). Therefore, the modulation of glucose metabolism by hormones occurs via the effect on the cellular clock, which, in its turn, affects leptin, regulating hexokinase- 3 and many other enzymes [80].

A great number of antioxidant system enzymes have E-boxes in the promoter site of genes, which testifies to the possibility of regulation by dimer CLOCK:BMAL1 [81].

Thus, glucose metabolism at the cellular level is a subject to the regulatory effect from the cellular clock system. This effect may be both direct, related to the activation of transcription of glucose metabolism genes, and mediated - due to the effect of the cellular clock on the kinase-phosphatase system. In addition, there is an inverse relation, pursuant to which the functioning of the cellular clock in peripheral tissues is modulated by hormones and regulators of carbohydrate exchange, reductive-oxidative state of the cytoplasm and glucose level.

However, not only cytoplasmatic and nuclear factors affect the gene expression of the first stages of glucose metabolism. Endoplasmatic network is one of key organelles in the cellular response to ischemia, hypoxia and some chemicals, activating the complex set of signaling pathways, reacting towards unfolded protein. This adaptive reaction is activated in conditions of accumulating unfolded proteins in endoplasmatic reticulum and is mediated by three resident EPR-sensors, PERK (PRK-like ER kinase), IRE1/ /ERN1 (inositol-requiring1/endoribonuclease 1) and ATF6 (activation transcriptional factor 6), but ERN1 is the main sensor [82, 83].

The activation of unfolded protein response (UPR) limits the release of new proteins to the endoplasmatic network and facilitates both protein folding in the endoplasmatic reticulum and the degradation, which is essential for cell adaptation, or, on the contrary, induces the programs of cellular death via mechanisms, related to the endoplasmatic network $[82,84]$. UPR is involved in the launch of cellular response to the accumulation of unfolded proteins in the opening of the endoplasmatic reticulum, occurring in both physiological and pathological conditions.

Two different catalytic domains of bifunctional signaling enzyme ERN1 were determined to be serine/threonine kinase and endoribonuclease, involved in ERN1-signaling. Kinase ERN1 autophosphorylates this enzyme, which results in its dimerization, activation of endoribonuclease domain and splicing of mRNA XBP1 (X-Box-binding protein 1) [83]. Mature splice-variants of mRNA XBP1 encode the transcriptional factor with modified C-terminal amino acid sequence and stimulate the expression of hundreds of specific genes, responding to unfolded or misfolded proteins [82, 83].

Moreover, during its growth a tumor requires the functional signaling system of endoplasmatic reticulum stress as well as hypoxia and ischemia for 
neovascularization and growth. Therefore, a complete blocking of the ERN1 signal transfer pathway has an antitumor effect $[85,86]$. The signaling pathway of endoplasmatic reticulum, activated in response to stress-reaction, is conditioned by the process of neovascularization, tumor growth and differentiation as well as death of cells [86].

Another system of regulating gene expression, including the glycolytic pathway, is related to HIF (hypoxia-inducible factor). In conditions of hypoxia the processes of formation of new capillary network are initiated; there is activation of metabolism processes, glycolysis, in particular [88], aimed at the adaptation of cells to hypoxia, which is considerably mediated by the activation of the transcriptional factor HIF [89]. Hypoxic effects were revealed to depend largely on the functional state of the ERN1 signaling enzyme system. It was demonstrated that the level of expression of hexokinase- 2 in conditions of hypoxia and ischemia is conditioned by the function of ERN1 signaling enzyme (Figure) $[87,90]$.

The level of mRNA HK1 in glioma cells is known to increase in conditions of hypoxia and while cultivating cells in glucose-free medium. In addition, the cultivation of cells in glutamine-free medium evokes considerable modification of the level of mRNA HK1 in them. The inactivation of gene ERN1 does not result in considerable change in the level of mRNA of hexokinase-1, but it eliminates the dependence of the expression of this gene on hypoxia and decreases the effect of glucose deficiency in the medium of cultivating cells on its expression level.

At the same time, in hypoxia conditions the level of $H K 2$ gene expression in glioma cells increases six times compared to HK1 gene, and twice - in glucose-free medium. In addition, the level of $H K 2$ gene expression increases due to the cultivation of glioma cells in glutamine-free medium. The exclusion of gene ERNI increases the expression of $H K 2$ gene and eliminates the dependence of the expression of the latter on the deficiency of glucose and glutamine in the medium of cultivating cells, also decreasing the effect of hypoxia on the expression level. The expression of glucoso-6phosphate dehydrogenase gene in glioma cells is increased in case of ERN1 gene exclusion, activating considerably in conditions of hypoxia and glutamine defi-

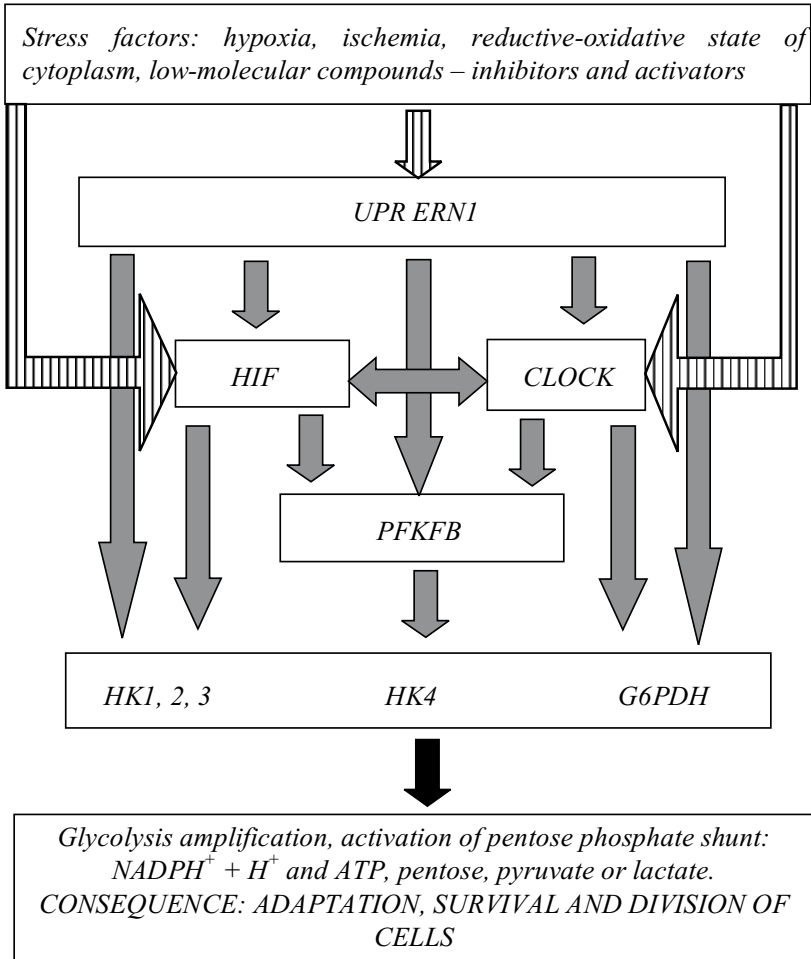

Figure. Regulatory effect on gene expression of hexokinases and glucoso-6-phosphate dehydrogenase of cell signaling systems

Legends: UPR ERN1 - system of endoplasmatic reticulum stress; HIF - hypoxia-inducible factor; $C L O C K$ - circadian clock system; $P F K F B$ - 6-phosphofructo-2-kinase/fructoso-2,6-bisphosphatase; $H K 1,2,3$, $H K 4$ - hexokinases; G6PDH - glucoso-6-phosphate dehydrogenase

ciency. Thus, the level of expression for genes $H K 1$ and $H K 2$ in glioma cells is considerably changed in conditions of hypoxia and ischemia and depends on the function of the gene of ERN1 signaling enzyme [87, 90].

The level of mRNA expression of glucoso-6-phosphate dehydrogenase is not impaired in glioma cells with inhibited function of the enzyme ERN1, but hypoxia decreases the expression of G6PDH considerably, while in conditions of glutamine and glucose deficiency there is a registered increase in the expression level of mRNA G6PDH in both types of glioma cells. This effect is most expressed in the control glioma cells in conditions of glutamine deficiency and in the cells with inhibited function of ERN1 in conditions of glucose deficiency [87, 90].

Therefore, the signaling system of endoplasmatic reticulum stress, HIF system and the system of circadian clock have regulatory effect on the course of glycolysis and pentose phosphate shunt via the 
regulation of mRNA expression for a number of key glycolysis enzymes. Therefore, the study of the expression of genes, controlling glucose metabolism, is an urgent trend of biochemical investigations, as it will allow revealing molecular mechanisms of expression regulation for these genes and the interaction of different genes, involved in carcinogenesis as well as elaborating new approaches to the creation of antitumor preparations.

\section{Р. Ю. Марунич}

Регуляція експресії генів гексокіназ і глюкозо-6-фосфатдегідрогенази за умов

норми і патології

ННЦ «Інститут біології» Київського національного університету імені Тараса Шевченка

Вул. Володимирська, 64/13, Київ, Україна, 01601

\section{Summary}

Посилення гліколізу у пухлинах за аеробних умов відоме як феномен Варбурга, при иььому значно акти ву- ється пентозофосфатний шунт. Пентозофосфатний иунт $і$ гліколіз, особливо їхні периі ланки та ре- гуляторний фермент 6-фосфофрукто-2-кіназа/фруктозо-2,6-бісфосфатаза піддаються впливу сигнальних систем клітини, таких як циркадіальний годинник, гіпоксія-індукуючий фактор і стрес ендо- плазматичного ретикулуму. Це дозволяє онкотрансформованим клітинам адаптуватися до стресових чинників, серед яких гіпоксія, ішемія $і$ дія низькомолекулярних агентів. Зроблено аналіз впливу сигнальних систем на експресію генів ключових ферментів гліколізу і пентозофосфатного иунту за нормальних умов та за умов онкологічної патології. Досліджено значення иього впливу для виживання онкотранс- формованих клітин за стресових умов.

Ключові слова: гексокінази, глюкозо-6-фосфатдегідрогеназа, експресія генів, стрес.

\section{Р. Ю. Марунич}

Регуляция экспрессии генов гексокиназ и глюкозо-6-

фосфатдегидрогеназы в условиях нормы и при патологии

\section{Резюме}

Усиление гликолиза в опухолях при аэробных условиях известно как феномен Варбурга, при этом также значительно возрастает активность пентозофосфатного шунта. Пентозофосфатный иунт и гликолиз, особенно их первые звенья и регуляторный фермент 6-фосфофрукто-2-киназа/фруктозо-2, 6-бисфосфатаза подвергаются влиянию сигнальных систем клетки, таких как ичикадиальные часы, гипоксия-индуцируюший фактор и стресс эндоплазматического ретикулума, что позволяет онкотрансформированным клеткам адаптироваться к стрессовым факторам, в частности, ишемии и действию низкомолекулярных агентов. Проведен анализ влияния сигнальных систем на экспрессию генов ключевых ферментов гликолиза и пентозофосфатного шунта при нормальных условиях и при патологии. Исследовано значение этого влияния для выживания онкотрансформованих клеток в стрессовых условиях.

Ключевые слова: гексокиназы, глюкозо-6-фосфатдегидрогеназы, экспрессия генов, стресс.

\section{REFERENCES}

1. Irwin D. M., Tan H. Molecular evolution of the vertebrate hexokinase gene family: identification of a conserved fifth vertebrate hexokinase gene // Comp. Biochem. Physiol. Part. D. Genomics Proteomics.-2008.-3, N 1.-P. 96-107.

2. Murakami K., Kanno H., Tancabelic J., Fujii H. Gene expression and biological significance of hexokinase in erythroid cells // Acta Haematol.-2002.-108, N 4.-P. 204-209.

3. Murakami K., Kanno H., Miwa S., Piomelli S. Human HKR isozyme: organization of the hexokinase I gene, the erythroid-specific promoter, and transcription initiation site // Mol. Genet. Metab.-1999.-67, N 2.-P. 118-130.

4. Hantke J., Chandler D., King R., Wanders R. J., Angelicheva D., Tournev I., McNamara E., Kwa M., Guergueltcheva V., Kaneva $R$., Baas $F$., Kalaydjieva L. A mutation in an alternative untranslated exon of hexokinase 1 associated with hereditary motor and sensory neuropathy - Russe (HMSNR) // Eur. J. Hum. Genet.2009.-17, N 12.-P. 1606-1614.

5. Marin-Hernandez A., Gallardo-Perez J. C., Ralph S. J., Rodriguez-Enriquez S., Moreno-Sanchez R. HIF-1alpha modulates energy metabolism in cancer cells by inducing over-expression of specific glycolytic isoforms // Mini Rev. Med. Chem.-2009.-9, N 9.-P. 1084-1101.

6. de Vooght K. M., van Solinge W. W., van Wesel A. C., Kersting $S$, van Wijk R. First mutation in the red blood cell-specific promoter of hexokinase combined with a novel missense mutation causes hexokinase deficiency and mild chronic hemolysis // Haematologica.-2009.-94, N 9.-P. 1203-1210.

7. de Vooght K. M., van Wijk R., van Oirschot B. A., Rijksen G., van Solinge $W$. $W$. Pyruvate kinase regulatory element 1 (PKR-RE1) mediates hexokinase gene expression in K562 cells // Blood Cells Mol. Dis.-2005.-34, N 2.-P. 186-190.

8. Heikkinen S., Suppola S., Malkki M., Deeb S. S., Janne J., Laakso $M$. Mouse hexokinase II gene: structure, cDNA, promoter analysis, and expression pattern // Mamm. Genome.-2000.-11, N 2.- P. 91-96.

9. Qiu M. Z., Han B., Luo H. Y., Zhou Z. W., Wang Z. Q., Wang F. H., Li Y. H., Xu R. H. Expressions of hypoxia-inducible factor$1 \alpha$ and hexokinase-II in gastric adenocarcinoma: the impact on prognosis and correlation to clinicopathologic features // Tumour Biol.-2011.-32, N 1.-P. 159-166.

10. Peng Q., Zhou J., Zhou Q., Pan F., Zhong D., Liang H. Silencing hexokinase II gene sensitizes human colon cancer cells to 5-fluorouracil // Hepatogastroenterology.-2009.-56, N 90.P. 355-360.

11. Kim J. W., Gao P., Liu Y. C., Semenza G. L., Dang C. V. Hypoxia-inducible factor 1 and dysregulated c-Myc cooperatively induce vascular endothelial growth factor and metabolic switches hexokinase 2 and pyruvate dehydrogenase kinase $1 / /$ Mol. Cell Biol.-2007.-27, N 21.-P. 7381-7393.

12. Gosmain Y., Lefai E., Ryser S., Roques M., Vidal H. Sterol regulatory element-binding protein-1 mediates the effect of insulin on hexokinase II gene expression in human muscle cells // Diabetes.-2004.-53, N 2.-P. 321-329. 
13. Yasuda S., Arii S., Mori A., Isobe N., Yang W., Oe H., Fujimoto A., Yonenaga Y., Sakashita H., Imamura M. Hexokinase II and VEGF expression in liver tumors: correlation with hypoxia-inducible factor 1 alpha and its significance // J. Hepatol.-2004.40, N 1.-P. 117-123.

14. Gwak G. Y., Yoon J. H., Kim K. M., Lee H. S., Chung J.W., Gores $G$. $J$. Hypoxia stimulates proliferation of human hepatoma cells through the induction of hexokinase II expression // J. Hepatol.2005.-42, N 3.-P. 358-364.

15. Haberkorn U., Hoffend J., Schmidt K., Altmann A., Bonaterra G. A., Dimitrakopoulou-Strauss A., Strauss L. G., Eisenhut M., Kinscherf $R$. Changes in glucose metabolism and gene expression after transfer of anti-angiogenic genes in rat hepatoma // Eur. J. Nucl. Med. Mol. Imaging.-2007.-34, N 12.-P. 20112023.

16. Ando M., Uehara I., Kogure K., Asano Y., Nakajima W., Abe Y., Kawauchi K., Tanaka N. Interleukin 6 enhances glycolysis through expression of the glycolytic enzymes hexokinase 2 and 6-phosphofructo-2-kinase/fructose-2,6-bisphosphatase-3 // J. Nippon Med. Sch.-2010.-77, N 2.-P. 97-105.

17. Colosimo A., Calabrese G., Gennarelli M., Ruzzo A. M., Sangiuolo F., Magnani M., Palka G., Novelli G., Dallapiccola B. Assignment of the hexokinase type 3 gene (HK3) to human chromosome band $5 \mathrm{q} 35.3$ by somatic cell hybrids and in situ hybridization // Cytogenet. Cell. Genet.-1996.-74, N 3.-P. 187-188.

18. Furuta H., Nishi S., Le Beau M. M, Fernald A. A, Yano H., Bell $G$. I. Sequence of human hexokinase III cDNA and assignment of the human hexokinase III gene (HK3) to chromosome band $5 q 35.2$ by fluorescence in situ hybridization // Genomics.-1996.36, N 1.-P. 206-209.

19. Coerver K. A, Gray S. M, Barnes J. E, Armstrong D. L, McCabe $E$. R. Developmental expression of hexokinase 1 and 3 in rats // Histochem. Cell. Biol.-1998.-109, N 1.-P. 75-86.

20. Bos R., van Der Hoeven J. J., van Der Wall E., van Der Groep P., van Diest P. J., Comans E. F., Joshi U., Semenza G. L., Hoekstra O. S., Lammertsma A. A., Molthoff C. F. Biologic correlates of (18) fluorodeoxyglucose uptake in human breast cancer measured by positron emission tomography // J. Clin. Oncol.-2002.20, N 2.-P. 379-387.

21. Fonteyne P., Casneuf V., Pauwels P., Van Damme N., Peeters M., Dierckx R., Van de Wiele $C$. Expression of hexokinases and glucose transporters in treated and untreated oesophageal adenocarcinoma // Histol. Histopathol.-2009.-24, N 8.-P. 971-977.

22. Sjoblom T., Jones S., Wood L. D., Parsons D.W., Lin J., Barber T. D., Mandelker D., Leary R. J., PtakJ., Silliman N., Szabo S., Buckhaults P., Farrell C., Meeh P., Markowitz S. D., Willis J., Dawson D., Willson J. K., Gazdar A. F., Hartigan J., Wu L., Liu C., Parmigiani G., Park B. H., Bachman K. E., Papadopoulos N., Vogelstein B., Kinzler K. W., Velculescu V. E. The consensus coding sequences of human breast and colorectal cancers // Science.-2006.-314, N. 5797.-P. 268-274.

23. Cardenas M. L., Cornish-Bowden A., Ureta T. Evolution and regulatory role of the hexokinases // Biochim. Biophys. Acta.1998.-1401, N 3.-P. 242-264.

24. Tiedge M., Steffeck H., Elsner M., Lenzen S. Metabolic regulation, activity state, and intracellular binding of glucokinase in insulin-secreting cells // Diabetes.-1999.-48, N 3.-P. 514-523.

25. Massa L., Baltrusch S., Okar D. A., Lange A. J., Lenzen S., Tiedge $M$. Interaction of 6-phosphofructo-2-kinase/fructose-2,6-bisphosphatase (PFK-2/FBPase-2) with glucokinase activates glucose phosphorylation and glucose metabolisminInsulin-producing cells // Diabetes.-2004.-53, N 4.-P. 1020-1029.

26. Hirota K., Sakamaki J., Ishida J., Shimamoto Y., Nishihara S., Kodama N., Ohta K., Yamamoto M., Tanimoto K., Fukamizu A.
A combination of HNF-4 and Foxol is required for reciprocal transcriptional regulation of glucokinase and glucose-6-phosphatase genes in response to fasting and feeding // J. Biol. Chem.2008.-283, N 47.-P. 32432-32441.

27. Egea M., Meton I., Cordoba M., Fernandez F., Baanante I. V. Role of Sp1 and SREBP-1a in the insulin-mediated regulation of glucokinase transcription in the liver of gilthead sea bream ( $\mathrm{Spa}$ rus aurata) // Gen. Comp. Endocrinol.-2008.-155, N 2.-P. 359367.

28. Gasperikova D., Tribble N.D., StanikJ., Huckova M., Misovicova N., van de Bunt M., Valentinova L., Barrow B. A., Barak L., Dobransky R., Bereczkova E., MichalekJ., Wicks K., Colclough K., Knight J. C., Ellard S., Klimes I., Gloyn A. L. Identification of a novel beta-cell glucokinase (GCK) promoter mutation (-71 $\mathrm{G}>\mathrm{C}$ ) that modulates $G C K$ gene expression through loss of allele-specific Sp1 binding causing mild fasting hyperglycemia in humans // Diabetes.-2009.-58, N 8.-P. 1929-1935.

29. Zhu L. L., Liu Y., Cui A. F., Shao D., Liang J. C., Liu X. J., Chen Y., Gupta N., Fang F. D., Chang Y. S. PGC-1 $\alpha$ coactivates estrogen-related receptor- $\alpha$ to induce the expression of glucokinase // Am. J. Physiol. Endocrinol. Metab.-2010.-298, N 6.-E12101218.

30. Wu C., Okar D. A., Newgard C. B., Lange A. J. Overexpression of 6-phosphofructo-2-kinase/fructose-2, 6-bisphosphatase in mouse liver lowers blood glucose by suppressing hepatic glucose production // J. Clin. Invest.-2001.-107, N 1.-P. 91-98.

31. Magnuson M. A., Niswender K. D., Pettepher C. C. Glucokinase gene expression and regulation // Molecular Biology of Diabetes.-Totowa: Yumana press, 1994.-Chapt. 7.-P. 155-174.

32. Estalella I., Rica I., Perez de Nanclares G., Bilbao J. R., Vazquez J. A., San Pedro J. I., Busturia M. A., Castano L., Spanish MODY Group Mutations in GCK and HNF-1alpha explain the majority of cases with clinical diagnosis of MODY in Spain // Clin. Endocrinol. (Oxf).-2007.-67, N 4.-P. 538-546.

33. Gomez-Zumaquero J. M., Rojo-Martinez G., Garcia-Escobar E., Martin-Nunez G. M., Haro J., Esteva I., Ruiz de Adana M., Cuesta A. L., Olveira G., Morcillo S., Soriguer F. The -30 G > A polymorphism of the glucokinase gene promoter is associated with obesity in a population from southern Spain // Obesity (Silver Spring).-2008.-16, N 8.-P. 1973-1975.

34. Garcia-Herrero C. M., Galan M., Vincent O., Flandez B., Gargallo M., Delgado-Alvarez E., Blazquez E., Navas M. A. Functional analysis of human glucokinase gene mutations causing MODY 2: exploring the regulatory mechanisms of glucokinase activity // Diabetologia.-2007.-50, N 2.-P. 325-333.

35. Gloyn A. L., Noordam K., Willemsen M. A., Ellard S., Lam W. W., Campbell I. W., Midgley P., Shiota C., Buettger C., Magnuson M. A., Matschinsky F. M., Hattersley A. T. Insights into the biochemical and genetic basis of glucokinase activation from naturally occurring hypoglycemia mutations // Diabetes.-2003.-52, N 9.P. 2433-2440.

36. Tinto N., Zagari A., Capuano M., De Simone A., Capobianco V., Daniele G., Giugliano M., Spadaro R., Franzese A., Sacchetti L. Glucokinase gene mutations: structural and genotype-phenotype analyses in MODY children from south Italy // PLoS ONE.2008.-3, N 4.-e1870.

37. Bosco D., Meda P., Iynedjian P. B. Glucokinase and glucokinase regulatory protein: mutual dependence for nuclear localization // Biochem. J.-2000.-348, Pt 1.-P. 215-222.

38. Chen X., Yue L., Li C. Li C. A novel G473A mutation in the glucose-6-phosphate dehydrogenase gene // Pediatr. Blood Cancer.2010.-55, N 2.-P. 383-385.

39. Al-Allawi N., Eissa A. A., Jubrael J. M., Jamal S. A., Hamamy H. Prevalence and molecular characterization of Glucose-6-Phos- 
phate dehydrogenase deficient variants among the Kurdish population of Northern Iraq // BMC Blood Disord.-2010.-10-P. 6.

40. Nouraie M., Reading N. S., Campbell A., Minniti C. P., Rana S. R., Luchtman-Jones L., Kato G. J., Gladwin M. T., Castro O. L., Prchal J. T., Gordeuk V. R. Association of G6PD with lower haemoglobin concentration but not increased haemolysis in patients with sickle cell anaemia // Br. J. Haematol.-2010.-150, N 2.P. 218-225.

41. Rank K. B., Harris P. K., Ginsberg L. C., Stapleton S. R. Isolation and sequence of a rat glucose-6-phosphate dehydrogenase promoter // Biochim. Biophys. Acta-1994.-1217, N 1.-P. 90-92.

42. Philippe M., Larondelle Y., Lemaigre F., Mariame B., Delhez H., Mason P., Luzzatto L., Rousseau G. G. Promoter function of the human glucose-6-phosphate dehydrogenase gene depends on two GC boxes that are cell specifically controlled // Eur. J. Biochem.-1994.-226, N 2.-P. 377-384

43. Zhong D. N., Gao Z. Y., Liu Y. N., Liu Y., Wei L. M. Relationship between glucose-6-phosphate dehydrogenase gene mutations and neonatal jaundice in Naning, Guangxi // Zhongguo Dang Dai Er Ke Za Zhi.-2009.-11, N 12.-P. 970-972.

44. Zhang Z., Liew C. W., Handy D. E., Zhang Y., Leopold J. A., Hu J., Guo L., Kulkarni R. N., Loscalzo J., Stanton R. C. High glucose inhibits glucose-6-phosphate dehydrogenase, leading to increased oxidative stress and $\beta$-cell apoptosis // FASEB J.-2010.-24, N 5.-P. 1497-1505.

45. Manco L., Goncalves P., Macedo-Ribeiro S., Seabra C., Melo P. Ribeiro M. $L$. Two new glucose-6-phosphate dehydrogenase mutations causing chronic hemolysis // Haematologica.-2005.-90, N 8.-P. 1135-1136.

46. San Millan J. L., Botella-Carretero J. I., Alvarez-Blasco F., Luque-Ramirez M., Sancho J., Moghetti P., Escobar-Morreale $H$. F. A study of the hexose-6-phosphate dehydrogenase gene $R 453 Q$ and 11 beta-hydroxysteroid dehydrogenase type 1 gene 83557ins A polymorphisms in the polycystic ovary syndrome // J. Clin. Endocrinol. Metab.-2005.-90, N 7.-P. 4157-4162.

47. Hellani A., Al-Akoum S., Abu-Amero K. K. G6PD Mediterranean $\mathrm{S} 188 \mathrm{~F}$ codon mutation is common among Saudi sickle cell patients and increases the risk of stroke // Genet. Test Mol. Biomarkers.-2009.-13, N 4.-P. 449-452.

48. Wagle A., Jivraj S., Garlock G. L., Stapleton S. R. Insulin regulation of glucose-6-phosphate dehydrogenase gene expression is rapamycin-sensitive and requires phosphatidylinositol 3-kinase // J. Biol. Chem.-1998.-273, N 24.-P. 14968-14974.

49. Xu C, Chakravarty K, Kong X, Tuy T. T, Arinze I. J, Bone F, Massillon $D$. Several transcription factors are recruited to the glucose6-phosphatase gene promoter in response to palmitate in rat hepatocytes and H4IIE cells // J. Nutr.-2007.-137, N 3.-P. 554-559.

50. Valverde A. M., Benito M., Lorenzo M. Hormonal regulation of malic enzyme and glucose-6-phosphate-dehydrogenase expression in fetal brown-adipocyte primary cultures under non-proliferative conditions // Eur. J. Biochem.-1992.-203, N 1-2.-P. 313-319.

51. Gao L., Mejias R., Echevarria M., Lopez-Barneo J. Induction of the glucose-6-phosphate dehydrogenase gene expression by chronic hypoxia in PC12 cells // FEBS Lett.-2004.-569, N 1- 3.P. 256-260.

52. Amir-Ahmady B., Salati L. M. Regulation of the processing of glucose-6-phosphate dehydrogenase mRNA by nutritional status // J. Biol. Chem.-2001.-276, N 13.-P. 10514-10523.

53. Doherty C. J., Kay S. A. Circadian control of global gene expression patterns // Annu. Rev. Genet.-2010.-44.-P. 419-444.

54. Siepka S. M., Yoo S. H, Park J., Lee C., Takahashi J. S. Genetics and neurobiology of circadian clocks in mammals // Cold Spring Harb. Symp. Quant. Biol.-2007.-72.-P. 251-259.
55. Panda S., Hogenesch J. B., Kay S. A. Circadian rhythms from flies to human // Nature.-2002.-417, N 6886.-P. 329-335.

56. Hogenesch J. B., Gu Y. Z., Jain S., Bradfield C. A. The basichelix-loop-helix-PAS orphan MOP3 forms transcriptionally active complexes with circadian and hypoxia factors // Proc. Natl Acad. Sci. USA.-1998.-95, N 10.-P. 5474-5479.

57. King D. P., Zhao Y., Sangoram A. M., Wilsbacher L. D., Tanaka M., Antoch M. P., Steeves T. D., Vitaterna M. H., Kornhauser J. M., Lowrey P. L., Turek F. W., Takahashi J. S. Positional cloning of the mouse circadian CLOCK gene // Cell.-1997.-89, N 4.P. 641-653.

58. Eide E. J., Vielhaber E. L., Hinz W. A., Virshup D. M. The circadian regulatory proteins BMAL1 and cryptochromes are substrates of casein kinase I epsilon // J. Biol. Chem.-2002.-277, N 19.P. $17248-17254$.

59. Sanada K., Okano T., Fukada Y. Mitogen-activated protein kinase phosphorylates and negatively regulates basic helix-loop-helix-PAS transcription factor BMAL1 // J. Biol. Chem.-2002.277, N 1.-P. 267-271.

60. Marunych R., Minchenko D., Kuznetsova A., Minchenko O. Quotidian dynamics of Clock, Bmall and Per 2 circadian genes expression in different rat tissues // Bull. of Taras Shevchenko National University of Kyiv. Series Biology.-2011.-58.- P. 18-22.

61. Semenza G. L. Oxygen-dependent regulation of mitochondrial respiration by hypoxia-inducible factor 1 // Biochem. J.-2007.405, N 1.-P. 1-9.

62. Teboul M., Barrat-Petit M. A., Li X. M., Claustrat B., Formento J. L., Delaunay F., Levi F., Milano G. Atypical patterns of circadian CLOCK gene expression in human peripheral blood mononuclear cells // J. Mol. Med.-2005.-83, N 9.-P. 693-699.

63. Eide E. J., Woolf M. F., Kang H., Woolf P., Hurst W., Camacho F., Vielhaber E. L., Giovanni A., Virshup D. M. Control of mammalian circadian rhythm by CKI-epsilon-regulated proteasomemediated PER2 degradation // Mol. Cell. Biol.-2005.-25, N 7.P. 2795-2807.

64. Okamura A., Iwata N., Tamekane A., Yakushijin K., Nishikawa S., Hamaguchi M., Fukui C., Yamamoto K., Matsui T. Casein kinase I $\varepsilon$ down-regulates phospho-Akt via PTEN, following genotoxic stress-induced apoptosis in hematopoietic cells // Life Sci.-2006.-78, N 14.-P. 1624-1629.

65. Waddell D. S., Liberati N. T., Guo X., Frederick J. P., Wang X. $F$. Casein kinase I $\varepsilon$ plays a functional role in the transforming growth factor- $\beta$ signaling pathway // J. Biol. Chem.-2004.-279, N 28.-P. 29236-29246.

66. Inoue A., Muranaka S., Fujita H., Kanno T., Tamai H., Utsumi $K$. Molecular mechanism of diclofenac-induced apoptosis of promyelocytic leukemia: dependency on reactive oxygen species, Akt, Bid, cytochrome and caspase pathway // Free Radic. Biol. Med.-2004.-37, N 8.-P. 1290-1299.

67. Wang W., El-Deiry W. S. Restoration of p53 to limit tumor growth // Curr. Opin. Oncol.-2008.-20, N 1.-P. 90-96.

68. Meric-Bernstam F., Akcakanat A., Chen H., Do K. A., Sangai T., Adkins F., Gonzalez-Angulo A. M., Rashid A., Crosby K., Dong M., Phan A. T., Wolff R. A., Gupta S., Mills G. B., Yao J. PIK3CA/ PTEN mutations and Akt activation as markers of sensitivity to allosteric mTOR inhibitors // Clin. Cancer Res.-2012.-18, N 6.P. $1777-1789$

69. Rutter J., Reick M., Wu L. C., McKnight S. L. Regulation of clock and NPAS2 DNA binding by the redox state of NAD cofactors // Science.-2001.-293, N 5529.-P. 510-514.

70. Kondratov R. V., Chernov M. V., Kondratova A. A., Gorbacheva V. Y., Gudkov A. V., Antoch M. P. BMAL1-dependent circadian oscillation of nuclear CLOCK: posttranslational events induced 
by dimerization of transcriptional activators of the mammalian clock system // Genes Dev.-2003.-17, N 15.-P. 1921-1932.

71. Yu W., Nomura M., Ikeda M. Interactivating feedback loops within the mammalian clock: BMAL1 is negatively autoregulated and upregulated by CRY1, CRY2 PER2 // Biochem. Biophys. Res. Commun.-2002.-290, N 3.-P. 933-941.

72. Preitner N., Damiola F., Lopez-Molina L., Zakany J., Duboule D., Albrecht $U$., Schibler $U$. The orphan nuclear receptor REV$\mathrm{ERB} \alpha$ controls circadian transcription within the positive limb of the mammalian circadian oscillator // Cell.-2002.-110, N 2.P. 251-260

73. Yagita K., Tamanini F., Yasuda M., Hoeijmakers J. H., van der Horst G. T., Okamura H. Nucleocytoplasmic shuttling and mCRY-dependent inhibition of ubiquitylation of the mPER2 clock protein // EMBO J.-2002.-21, N 6.-P. 1301-1314.

74. Bunger M. K., Wilsbacher L. D., Moran S. M., Clendenin C., Radcliffe L. A., Hogenesch J. B., Simon M. C., Takahashi J. S., Bradfield C. A. Mop3 is an essential component of the master circadian pacemaker in mammals // Cell.-2000.-103, N 7.-P. 10091017.

75. Loboda A., Kraft W. K., Fine B., Joseph J., Nebozhyn M., Zhang C., He Y., Yang X., Wright C., Morris M., Chalikonda I., Ferguson M., Emilsson V., Leonardson A., Lamb J., Dai H., Schadt E., Greenberg H. E., Lum P. Y. Diurnal variation of the human adipose transcriptome and the link to metabolic disease // BMC Med. Genomics.-2009.-2.-P. 7.

76. Hirota T., Okano T., Kokame K., Shirotani-Ikejima H., Miyata T., Fukada Y. Glucose down-regulates Per1 and Per2 mRNA levels and induces circadian gene expression in cultured Rat-1 fibroblasts // J. Biol. Chem.-2002.-277, N 46.-P. 44244-44251.

77. Yin L., Wu N., Lazar M. A. Nuclear receptor Rev-erb $\alpha$ : a heme receptor that coordinates circadian rhythm and metabolism // Nucl. Recept. Signal.-2010.-8.--e8.

78. Raspe E., Duez H., Mansen A., Fontaine C., Fievet C., Fruchart J. C., Vennstrom B., Staels B. Identification of Rev-erb $\alpha$ as a physiological repressor of apoC-III gene transcription // J. Lipid Res.-2002.-43, N 12.-P. 2172-2179.

79. Doi R., Oishi K., Ishida N. CLOCK regulates circadian rhythms of hepatic glycogen synthesis through transcriptional activation of Gys2 // J. Biol. Chem.-2010.-285, N 29.-P. 22114-22121.

80. So A. Y., Bernal T. U., Pillsbury M. L., Yamamoto K. R., Feldman B. J. Glucocorticoid regulation of the circadian clock modulates glucose homeostasis // Proc. Natl Acad. Sci. USA.-2009.106, N 41.-P. 17582-17587.
81. Kondratov R. V., Vykhovanets O., Kondratova A. A., Antoch M. P. Antioxidant $\mathrm{N}$-acetyl-L-cysteine ameliorates symptoms of premature aging associated with the deficiency of the circadian protein BMAL1 // Aging (Albany NY).-2009.-1, N 12.- P. 979-987.

82. Aragon T., van Anken E., Pincus D., Serafimova I. M., Korennykh A. V., Rubio C. A., Walter P. Messenger RNA targeting to endoplasmic reticulum stress signalling sites // Nature.-2009.-457, N 7230.-P. 736-740.

83. Romero-Ramirez L., Cao H., Nelson D., Hammond E., Lee A. H., Yoshida H., Mori K., Glimcher L. H., Denko N. C., Giaccia A. J., Le Q. T., Koong A. C. XBP1 is essential for survival under hypoxic conditions and is required for tumor growth // Cancer Res.2004.-64, N 17.-P. 5943-5947.

84. Auf G., Jabouille A., Guerit S., Pineau R., Delugin M., Bouchecareilh M., Magnin N., Favereaux A., Maitre M., Gaiser T., von Deimling A., Czabanka M., Vajkoczy P., Chevet E., Bikfalvi A., Moenner $M$. Inositol-requiring enzyme $1 \alpha$ is a key regulator of angiogenesis and invasion in malignant glioma // Proc. Natl Acad. Sci USA.-2010.-107, N 35.-P. 15553-15558.

85. Moenner M., Pluquet O., Bouchecareilh M., Chevet E. Integrated endoplasmic reticulum stress responses in cancer // Cancer Res.-2007.-67, N 22.-P. 10631-10634.

86. Minchenko D.O., Marunych R. Y., Khomenko E. V., Bakalets T. $V$., Minchenko O. H. Expression of hexokinase and 6-phosphofructo-2-kinase/fructose-2,6-bisphosphatase genes in ERN1 knockdown glioma U87 cells: effect of hypoxia and glutamine or glucose deprivation // Stud. Biol.-2011.-5, N 3.-P. 5-18.

87. Minchenko A., Leshchinsky I., Opentanova I., Sang N., Srinivas V., Armstead V., Caro J. Hypoxia-inducible factor-1-mediated expression of the 6-phosphofructo-2-kinase/fructose-2,6-bisphosphatase-3 (PFKFB3) gene. Its possible role in the Warburg effect // J. Biol. Chem.-2002.-277, N 8.-P. 6183-6187.

88. Minchenko O., Opentanova I., Minchenko D., Esumi H. Hypoxia induces transcription of 6-phosphofructo-2-kinase/fructose-2, 6-bisphosphatase 4 gene via hypoxia-inducible factor- $1 \alpha$ activation // FEBS Lett.-2004.-576, N 1-2.-P. 14-20.

89. Marunych R. Y., Minchenko D. O., Kubaichuk K. I., Bakalets T. $V$., Minchenko O. H. Effect of hypoxia and ischemia on the expression of phosphofructokinase-1 and lactate dehydrogenase genes in glioma U87 cells with ERN1 knockdown // Physics Alive.-2011.-19, N 1.-P. 50-62.

Received 07.02.13 